\title{
SELF-PROTECTION FOR EMERGING MARKET ECONOMIES
}

\author{
Martin Feldstein \\ Working Paper 6907 \\ http://www.nber.org/papers/w6907
NATIONAL BUREAU OF ECONOMIC RESEARCH
1050 Massachusetts Avenue
Cambridge, MA 02138
January 1999

The views expressed here are those of the author and do not reflect those of the National Bureau of Economic Research.

- 1999 by Martin Feldstein. All rights reserved. Short sections of text, not to exceed two paragraphs, may be quoted without explicit permission provided that full credit, including ${ }^{\circledR}$ notice, is given to the source. 
Self-Protection for Emerging Market Economies

Martin Feldstein

NBER Working Paper No. 6907

January 1999

JEL No. F3

\begin{abstract}
International economic crises will continue to occur in the future as they have for centuries past. The rapid spread of the 1997 crisis in Asia and of the 1982 crisis in Latin America showed how shifts in market perceptions can suddenly bring trouble to countries even when there has been no change in objective conditions. More recently, the sharp jump in emerging market interest rates after Russia's August 1998 default underlined the vulnerability of all emerging market economies to increases in investors' aversion to risk.

Emerging market countries that want to avoid the devastating effects of such crises must protect themselves. They cannot depend on the International Monetary Fund or other international organizations nor expect that a "new global financial architecture" will make the world economy less dangerous. Taking steps to protect themselves requires more than avoiding those bad policies that make a currency crisis inevitable. The process of contagion makes even the virtuous vulnerable to currency runs.

Liquidity is the key to self-protection. A country that has substantial international liquidity -large foreign exchange reserves and a ready source of foreign currency loans -- is less likely to be the object of a currency attack. Substantial liquidity also permits a country that is attacked from within or without to defend itself better and to make more orderly adjustments. The challenge is to find ways to increase liquidity at reasonable cost.
\end{abstract}

\author{
Martin Feldstein \\ Harvard University and NBER \\ 1050 Massachusetts Avenue \\ Cambridge, MA 02138 \\ feldstein@nber.org
}




\title{
Self-Protection for Emerging Market Economies
}

\author{
Martin Feldstein*
}

International economic crises will continue to occur in the future as they have for centuries past. The rapid spread of the 1997 crisis in Asia and of the 1982 crisis in Latin America showed how shifts in market perceptions can suddenly bring trouble to countries even when there has been no change in objective conditions. More recently, the sharp jump in emerging market interest rates after Russia's August 1998 default underlined the vulnerability of all emerging market economies to increases in investors' aversion to risk.

Emerging market countries that want to avoid the devastating effects of such crises must protect themselves. They cannot depend on the International Monetary Fund or other international organizations nor expect that a "new global financial architecture" will make the world economy less dangerous. Taking steps to protect themselves requires more than avoiding those bad policies that make a currency crisis inevitable. The process of contagion makes even the virtuous vulnerable to currency runs.

Liquidity is the key to self-protection. A country that has substantial international liquidity -large foreign exchange reserves and a ready source of foreign currency loans -- is less likely to be the object of a currency attack. Substantial liquidity also permits a country that is attacked from within or without to defend itself better and to make more orderly adjustments. The challenge is to find ways to increase liquidity at reasonable cost.

"Professor of Economics, Harvard University, and President of the National Bureau of Economic Research.

SelfProt. 122198 
The need for enhanced liquidity reflects the inevitable absence of an international lender of last resort. Within any national economy the central bank is the ultimate source of liquidity to the banking system and therefore to the economy. A solvent commercial bank (i.e., one with assets that exceed its liabilities when both are evaluated at fair market value) may not have enough liquid assets to pay depositors if many of them demand their funds at once. To prevent or contain a run of depositors, central banks follow the advice provided more than a century ago by Walter Bagehot: a central bank, as the lender of last resort in a financial crisis, must lend "freely, at penalty interest rates, on appropriate collateral."

There is no equivalent international lender of last resort that provides foreign exchange to countries that are temporarily illiquid but ultimately solvent in the sense that they could repay such loans with export earnings. Although the International Monetary Fund has organized large packages of credits for crisis countries, it does not "lend freely" at a time of need but disburses its funds gradually as the crisis countries meet a series of detailed conditions. Because the IMF's conditions are onerous and complex, private creditors cannot know whether funds will actually be available. The IMF loan packages are therefore not available to provide confidence to the financial markets that the country will have enough foreign exchange reserves to defend itself against speculators and others who would sell the currency.

There is a fundamental difference between the IMF and national central banks that prevents the IMF from ever acting as a lender of last resort. A national central bank can create as much of the domestic currency as its banking system wants. In contrast, the ability of the IMF to provide dollars or other hard currencies is constrained by the limited size of its capital. 
The plan for an new "enhanced" IMF lending facility announced by the G-7 countries in October 1998 would in principle provide funds quickly to countries before a crisis occurs. However, the proposal provides that funds would only be available to "pre-approved" countries that are deemed to be "pursuing strong IMF-approved policies." None of the Asian countries that experienced crises in 1997 would have been able to meet this test. The loan to Brazil announced in November 1998 was not part of this new arrangement (which had not yet been adopted by the IMF) and was made at a time when the Brazilian government had not passed the key legislation required to achieve reduced fiscal and trade deficits. Although it was described as an attempt to lend before a crisis began, these funds were also scheduled to be paid only gradually as Brazil met a variety of stringent conditions on budget policy.

It is not at all clear how the proposed pre-approval plan would work in practice. In the end, the IMF might simply try to use it to impose the same kinds of inappropriately intrusive economic restructuring on countries as it did in its post-crisis plans in Asia (see my "Refocusing the IMF," Foreign Affairs, March-April 1998.) If so, few countries might be willing to participate.

More generally, the new G-7 proposal is fundamentally misconceived because it focuses on countries that are in what might be called the "immediate pre-crisis stage" instead of recognizing that most emerging market countries need increased liquidity to reduce their risk of crisis and to manage crises when they occur. Even with the recently increased IMF capital provided by the United States and other members, the IMF does not have enough funds to finance a substantial number of such contingent loans. Nor is there any plan to assure the "appropriate private sector involvement" (i.e., to induce banks and bondholders to roll over existing private credits) that the G-7 plan assumes. Using national governments to force private creditors to continue lending to a country experiencing 
a currency crisis would decrease the "moral hazard" of excessive lending in good times but only at the cost of substantially reducing the long-term availability of funds to emerging market economies.

This article shows the role of liquidity in the origin and management of currency crises. I discuss two possible ways to increase liquidity: a low cost increase in foreign exchange reserves based on a strategy of investing reserves in a broader range of assets, and a new voluntary national credit facility collateralized with export earnings.

\section{Fluctuating Exchange Rates}

Although sharp swings in currency values can have a powerful destructive force on national economies, the normal fluctuations of exchange rates make a positive contribution to economic wellbeing by guiding capital to better uses around the world. If Mexican business investment becomes more profitable, Mexican interest rates rise and Mexican stocks become more attractive. Foreign portfolio investors buy pesos to invest in Mexican stocks and bonds while foreign companies buy pesos to acquire or build new businesses in Mexico. The rising peso reduces Mexico's exports and increases its imports, providing the extra flow of capital and of real resources to invest in local businesses. When Mexican investment becomes less profitable, investors sell the peso and direct capital to other countries where it can be used more productively.

In guiding the global flow of capital, currencies function like stocks, bonds and other financial assets. Banks, pension funds and other financial investors choose investments in different currencies on the basis of the expected yield and associated risk. Investors buy a currency they expect will rise in value and sell one they expect to fall. A higher interest rate attracts funds to a currency unless its value is expected to fall enough to outweigh the interest rate advantage. 
Importantly, it's not necessary to own a currency in order to sell it. Foreign investors who think the peso will fall relative to the dollar can borrow pesos, sell them for dollars and invest the dollars, expecting that after the peso's fall they will sell their dollar asset and repay the peso debt with depreciated pesos. That means that a currency's value can be driven down not only when it is sold by domestic residents or by foreign investors who initially held the currency but even by an international investor who borrows the currency in order to take advantage of his anticipation that it will decline in value.

Because expectations drive exchange rates, the fluctuations in currency values can be large and rapid. The Asian experience shows the serious damage that a sharp currency decline can cause. The most substantial immediate effect of a sharp fall in a currency is to increase the value of debts denominated in foreign currencies. When the Thai baht fell from 25 baht per dollar in June 1997 to more than 50 baht per dollar in January 1998, the number of baht that a Thai company needed to repay its dollar denominated debt more than doubled. In addition, a falling currency raises the price of imports and gives domestic producers the ability to increase prices as well. This causes higher inflation unless the government raises interest rates, depressing domestic production and employment still further. The problem becomes more acute as the size of the tradable sector grows, a particularly important issue for many smaller economies with large flows of exports and imports.

To prevent these inflationary pressures and the increases in the value of foreign debts, many governments use foreign exchange reserves and monetary policy to try to avoid what they see as irrational and unfounded shifts in currency values or to try to slow any process of adjustment. If private investors want to sell the currency, the government may use its dollar reserves to buy the currency or raise interest rates to induce investors to hold the currency. 
Exchange rate policy is complicated by the fact that many governments also control the exchange rate as a form of self-discipline to achieve a non-inflationary monetary policy. Since a lax monetary policy that causes inflation also causes the value of the national currency to decline, a government that commits itself to a fixed exchange rate relative to the dollar is implicitly committing itself to the same low inflation rate as that in the United States. If its commitment to a fixed exchange rate is believed by domestic business and labor, they will be less likely to try to raise prices and wages. Although low inflation could in principle be achieved without such an external anchor, governments have often found that this is a useful way of reducing inflation and keeping it down. Unfortunately, despite this virtuous intent, policies of fixed exchange rates are often a prelude to a currency crisis.

\section{Four Types of Crises}

\section{Current Account Crises}

An exchange rate that is fixed at a level that causes an increasing trade deficit inevitably leads to an attack on the currency, a loss of foreign exchange reserves, and a corrective fall in the exchange rate. The currency may be at a level that causes a trade deficit because it was initially set too high, or because domestic inflation made its prices internationally uncompetitive at that exchange rate, or because of currency devaluations in competing countries.

Thailand "fixed" its exchange rate at 25 baht to the dollar in 1987 and promised to use whatever policies were needed to keep it there. By the mid-1990s the baht was grossly overvalued, leading to a current account deficit (the combination of the trade deficit and the net interest due on foreign debts) equal to 8 percent of Thailand's GDP, one of the highest anywhere in the world.

Any current account deficit must be financed with an equally large inflow of funds from the rest of the world. Because of the Thai government's promise that the baht-dollar exchange rate 
would remain fixed, Thai banks and non-financial businesses felt comfortable about borrowing dollars at low interest rates to finance activities in Thailand. Similarly, foreign creditors were willing to lend in order to get the slightly higher rate of interest available in Thailand.

The banks and the foreign lenders both recognized that there was some risk in what they were doing. The unprecedentedly large current account deficit could be sustained only as long as foreign investors and lenders were prepared to keep sending money to Thailand, increasing their total Thai exposure. If the day came when they were no longer willing to do so, the current account would have to shrink to the amount that could be financed with the available capital inflow. Shrinking the current account deficit would require a lower value of the baht to make Thai exports more attractive and to reduce imports. The fall in the baht would hurt Thai banks and businesses that had borrowed dollars. Foreigners who lent baht would also be losers when the currency fell and those who lent dollars would be at risk that the Thai banks and businesses to which they had lent would be unable to repay their dollar obligations.

Thailand's massive current account deficit and the foreign lending to Thailand that financed that deficit lasted a surprisingly long time. But eventually fear outweighed greed and foreigners were no longer willing to keep lending. As the baht began to fall, nervous investors with baht assets who had no idea how far it might decline sold baht. Others borrowed baht in order to sell it on the presumption that the baht would continue to decline. The government tried to maintain the value of the baht but eventually exhausted its foreign reserves in the process and was unable to do so. Before the baht stopped falling, its value had declined by more than half, from 25 baht to the dollar to more than 50 baht to the dollar. 
Thailand could have avoided the loss of its reserves and probably had a smaller and less painful adjustment if it had abandoned the fixed exchange rate earlier and allowed the baht to find a level in the market. By the end of 1998, the market panic had subsided and the baht had settled to 36 baht per dollar. But although it is easy to criticize Thailand in retrospect, countries like Thailand delay abandoning the fixed rate or devaluing its level because doing so inevitably brings inflation, higher interest rates, and increased foreign debt burdens. In contrast, there was always the hope that the overvaluation might correct itself without a change in the nominal exchange rate if domestic prices fell or the dollar (to which the baht was tied) declined in value relative to other global currencies. (Such strategies are sometimes successful. Argentina rejected the criticisms of its fixed "overvalued" dollar-peso exchange rate and was able to remain competitive because its domestic producers lowered the cost of Argentine products by increasing productivity.)

An overvalued currency and the associated capital inflow are also helpful as long as they last, keeping import prices down and export prices up while providing a capital inflow to finance profitable domestic investments. After more than a decade of current account deficits, Thailand had hoped that it would be able to go on financing those deficits and therefore to continue adding more to its productive capital than it could finance with domestic savings alone.

The specific facts in Thailand's case may have made a currency devaluation inevitable, especially after the decline of the Japanese yen and the weakness of the Japanese economy caused Japanese imports from Thailand to decline. But the situation is never completely certain and a country that has enough international liquidity - large foreign exchange reserves and access to additional credits denominated in dollars or yen - can try to sustain the high value of its currency. 
With sufficient liquidity, a country can challenge the speculators and others who sell the currency, buying the currency to maintain its value or even driving the currency's value temporarily higher to "punish" those who bet against it. Speculation against a currency is also expensive because the interest rate on the currency being sold is generally substantially higher than the rate on the dollar or yen. Speculators who have much to lose through a possible rise in the currency value and the extra interest that they pay will therefore be attracted to bet only against the currencies that look particularly vulnerable. Large reserves and access to substantial additional foreign loans can reduce that vulnerability and increase confidence in the currency, thereby reducing the likelihood of an attempt to profit from a decline in the currency's value. But doing so requires reserves that are much larger than most emerging market countries have traditionally held.

The decision of when to use reserves in this way and when to accept a devaluation is not a purely economic issue with a technically correct solution that can be provided by the IMF or other advisers but involves a balancing of risks that is the essential responsibility of a sovereign government.

\section{Balance Sheet Crises}

A country may have a market-determined "floating" exchange rate and a current account surplus but still come under attack because its short-term private and government liabilities denominated in foreign currencies exceed its foreign exchange reserves. Such a country may be solvent in the sense that it can service its foreign currency debts with its future export earnings but is temporarily illiquid because it does not have the funds with which to meet its immediate obligations. If foreign creditors have confidence in the country and its currency, they will continue to roll over the short-term debts or extend their maturity. But if enough foreign creditors worry that the country will 
not be able to meet its obligations because other foreign creditors will not continue to lend, the country will be forced to default or to reschedule its loans and to devalue its currency in order to increase export earnings to repay its debts more quickly.

Korea's experience in 1997 is a good example of a balance sheet crisis. After Korea deregulated part of its banking system in the early 1990s, a group of small investment banks used their new freedom to borrow foreign currencies with short maturities and invested those funds in Korean won assets and in high risk foreign securities like Russian bonds. By late 1997, the value of the foreign obligations due within 12 months exceeded Korea's official foreign currency reserves. International investors, nervous after the collapse of the Thai baht and other Asian currencies in the previous few months, focused on Korea's balance sheet mismatch of assets and liabilities and began to sell the Korean won.

Korea could have stopped the inappropriate foreign borrowing and, with Korea's strong export performance, could have earned enough foreign currency to repay the existing foreign obligations. But it could not do so quickly enough if the foreign creditors all demanded payment and refused to roll-over existing obligations. In short, Korea was solvent but illiquid, i.e., able to meet its obligations given enough time but unable to do so immediately.

Had Korea not allowed its liquidity to deteriorate in this way, there need not have been any crisis in Korea. But global financial investors saw that Korea did not have adequate liquidity and that a won devaluation was likely to occur. Financial investors converted the won that they already owned or borrowed won and then sold those funds for dollars. Before the end of the year, the Korean currency had collapsed and the Korean government was in the hands of the IMF.

$\underline{\text { Bank-Run Currency Crises }}$ 
A common feature of the Asian currency crises has been the widespread failure of domestic banks. Many of these failures were the result of the currency decline which raised the value of the banks' dollar liabilities relative to its domestic currency assets. The currency decline also hurt banks with dollar denominated loans (as in Thailand) because the corporate borrowers had dollar liabilities and local currency income. But even before the currency decline, the banks failed because they had accumulated so many bad loans and other investments that their liabilities to depositors exceeded the true value of their loans and other assets.

Banks can retain deposits only as long as depositors remain confident that they can withdraw their funds on demand. When depositors get nervous that a bank run will leave the bank without the ability to meet further withdrawal requirements, the fear of a bank run becomes self-fulfilling.

Depositors may also fear that the national central bank will act as a lender of last resort to banks that are temporarily illiquid but will not help insolvent banks (where liabilities exceed the true value of assets.) Because depositors do not know the true condition of individual banks, the safest thing for depositors who fear bank insolvency to do is to withdraw funds from all domestic banks and seek a safe haven by depositing those funds abroad. If enough depositors want to do this, there will be a serious run on the currency that reduces its value. If the government tries to resist, it will deplete its foreign reserves and increase the risk of an exchange rate collapse. (A run on domestic banks need not cause a currency run if depositors can shift their funds to local banks that are owned abroad and therefore backed by strong overseas banks and by their central banks.)

The obvious and widely proffered advice for avoiding such runs is that emerging economy governments should not direct commercial banks to favor particular industries or firms and should improve the quality of their banking supervision so that widespread insolvencies do not occur. The 
former runs contrary to many national development strategies while the latter is hard to implement in practice, as the experience in the United States, Japan and many European countries has repeatedly shown. Insolvencies and banking crises will therefore occur.

Sufficient international liquidity in the form of either foreign currency reserves or access to foreign credit might allow a government to restructure and recapitalize its banks without experiencing such a currency crisis. The more international liquidity a government has, the less depositors will feel that they must rush to convert their currency before the reserves are depleted. And preventing a currency decline can be the best way to protect the banks' solvency.

Contagion Crises and Irrational Speculation

Finally, there can be currency declines that are not due to current account imbalances, to balance sheet mismatches, or to banking system failures. Even a currency that is allowed to float freely can be subject to a sharp drop, just as the value of individual stocks on the New York Stock Exchange can swing substantially in response to new information or to shifts in market psychology. Currencies that do not need to decline in order to shrink a current account deficit or to correct a balance sheet mismatch may nevertheless be pushed down by contagion based on geography, trade patterns, investors' portfolio strategies, and other conditions. Such currency declines can trigger rising inflation, or an economic downturn based on the increased debt burden, or both. A country with sufficient liquid international assets or credit availability can intervene in the currency market to defend its currency from unjustified pressures. The very presence of that liquidity is likely to promote the confidence among market participants the reduces the likelihood of irrational speculation. The traditional alternative, defending the currency by raising interest rates is often ineffective in itself while 
depressing the domestic economy and, by reducing the value of the local stock market, may actually exacerbate the capital outflow.

\section{Increasing International Liquidity}

An emerging economy can increase its net liquidity by reducing short-term foreign liabilities, by accumulating liquid reserves, and by organizing a collateralized credit facility. Each of these has its cost, which is why countries are tempted to do nothing and to take the risk of a currency crisis. But the Asian experience shows that the very large costs of a currency crisis may significantly exceed the costs of maintaining enough liquidity to achieve a substantial reduction in the risk of crisis.

The three ways of increasing liquidity are mutually reinforcing. Doing some of each reduces the cost of doing the others. A cost-effective strategy therefore probably involves doing some of all three. A major challenge is to develop new ways to reduce the costs of doing so.

\section{$\underline{\text { Avoiding Excessive Short-Term Foreign Debt }}$}

Banks, companies and governments in emerging market countries borrow with shortmaturities in dollars or yen because such loans have lower interest rates than longer-term or domestic currency loans. But such funds are particularly risky because foreign lenders may refuse to renew lending if conditions in the borrowing country appear to change or if lenders become more risk averse in general (as they did after the August 1998 Russian default.) Just the accumulation of too much such debt relative to reserves may trigger a currency crisis, as Korea learned at the end of 1997. And if a currency decline occurs, the increased local value of the dollar denominated debt can cause corporate bankruptcies and a decline of economic activity.

Chile successfully discouraged such short-term capital inflows by requiring borrowers to deposit 20 percent of foreign loans with the government for six months without interest, a very 
substantial penalty for short-term borrowing but not for long-term capital inflows. Several studies have shown that the total capital inflow to Chile was not reduced by this policy but that the composition of funds was shifted to less volatile forms.

Although substituting longer-term debt and equity funds for short-term borrowing raises the cost of capital to Chile's private borrowers, it was a successful way of reducing the risk of a currency crisis. The Chileans have also shown that this incentive mechanism can be varied in response to changing conditions. It is certainly a technique that more countries will be thinking about in conjunction with the increased monitoring of their country's overall foreign asset and liability positions.

Short-term foreign debt is of course not the only source of risk. In countries without capital controls, which includes most of the ASEAN countries and the countries of Latin America, local residents have the right to convert any amount of their cash or bank deposits from the local currency to foreign currencies. Unless limited by the government, the amount of such convertible deposits can be increased rapidly by bank lending. Limiting short term debts to less than foreign exchange reserves is not enough to achieve the desired level of international liquidity. Although the unwillingness of foreign creditors to roll over existing loans may be the most probable danger, the magnitude of widespread capital flight by domestic residents and of speculation by foreigners who borrow and sell the domestic currency may be the greater risk.

\section{Accumulating Foreign Exchange Reserves}

The most direct way for a country to achieve liquidity is to accumulate large amounts of liquid foreign reserves. China's reserves of more than $\$ 140$ billion send a strong signal to international investors and domestic residents that China will not be forced to devalue the yuan. But many 
countries with floating exchange rates, which in principle would have no need for reserves if they actually intend to let the value of their currency be determined exclusively by market forces, have substantial reserves to reduce the risk of rapid and substantial currency declines.

Reserves are costly in two ways. First, accumulating the reserves through trade surpluses requires the country to export more than it imports, implying less domestic consumption and investment than would otherwise prevail. Second, when the government buys foreign currency from its exporters and issues domestic bonds in exchange, the government pays a much higher rate of interest on its domestic bonds than it receives on reserves which in practice are invested in low yielding U.S. Treasury bills.

Accumulating reserves by running a trade surplus is also at best a slow process. In addition, keeping the export earnings as reserves rather than investing them in domestic infrastructure or making the funds available for private business investments involves sacrificing a substantial real rate of return for the nation.

Reserves can be accumulated more quickly and without reducing real domestic investment by borrowing abroad with medium or long-term maturities and then investing those funds in liquid easily-marketed securities, essentially the strategy that China, with $\$ 160$ billion of total foreign liabilities, has implicitly adopted. But this strategy can also be quite expensive. Mexico, for example would now pay an 11 percent interest rate on a twenty year bond, six percentage points more than it would earn on an investment in US Treasury bills. Thirty billion dollars of additional reserves, enough to double its current reserves, would therefore cost Mexico two billion dollars a year.

Although this price may seem high ( $\$ 2$ billion is nearly 0.5 percent of Mexico's GDP), it must be compared to the value of reducing the likelihood of another currency crisis. Moreover, the $\$ 2$ 
billion price tag may overstate the true national cost of such reserves because having the reserves may lower the cost of other Mexican private debt and equity capital. It is noteworthy that China, with very large reserves, pays interest of only about 7 percent on its long-term bonds.

A country could substantially lower the net cost of holding reserves by investing them in liquid assets with higher yields than Treasury bills. US corporate stocks had a real yield of 7 percent in the half century through 1995, more than 6 percentage points higher than the real yield on Treasury bills over the same period. Although corporate stocks are riskier than Treasury bills, a country could lower its overall risk by having larger foreign exchange reserves invested partly in stocks than smaller reserves invested solely in Treasury bills.

Many governments still judge the adequacy of their reserves in relation to the value of imports. But a reserve goal of "six months of imports" ignores the fact that currency crises are about capital flows, not trade financing. What matters is the value of reserves relative to the amount of the currency that speculators might sell when the country's fundamental economic conditions do not warrant a currency decline.

\section{Creating a Collateralized Credit Facility}

A country's ability to borrow large sums of foreign exchange on short notice is virtually as useful as holding an equal amount of reserves. The G-7 was right to emphasize the desirability of a pre-crisis loan fund but wrong to expect the IMF and the G-7 governments to provide the loans. The IMF has less than $\$ 200$ billion of total lending capacity, not a large number in comparison to the 1998 package of $\$ 42$ billion for Brazil alone. The Japanese government's plan to help Asian governments by guaranteeing their debts involved only $\$ 15$ billion of Japanese funds. In contrast the American 
banks alone have more than $\$ 5,000$ billion in outstanding loans and investments. The real challenge is to utilize private lines of credit from banks and other investors in industrial countries.

The G-7 called for continued lending to emerging market borrowers by the private creditors during times of economic stress. It is hard, however, to imagine why banks and bond holders would not try to reduce their exposure under those circumstances, even if international organizations and private rating agencies make reassuring statements. The only reliable way to maintain private lending and increase the volume of credit as a substitute for additional foreign reserves is to create a collateralized credit facility, an explicit agreement that provides collateral to protect the banks and other providers of credit. Although there is no substitute for sound economic behavior, creditors value good collateral more than the appearance of virtue. And with collateral there is no need to argue about whether a country is unable to meet its debt service requirements or is just unwilling to do so.

Done properly, such a facility could substitute for an international lender of last resort, lending freely at penalty interest rates against good collateral. The problem of course is to identify collateral that banks and bond holders could rely on in the case of default. Such collateral cannot be real estate or other domestic assets in the emerging market country which would be difficult for creditors to take and equally difficult to convert into dollars or other hard currencies.

The most suitable collateral would be trade receivables, i.e., the export earnings in hard currencies of the domestic firms. Such collateral is now common in many private credit arrangements between firms in emerging economies and their industrial country creditors. A collateralized facility was also used by the United States and Mexico in 1983 and again in 1995, with a dollar loan secured by the receipts from the Mexican government's future oil sales. (Argentina now has an essentially 
uncollateralized $\$ 7$ billion line of credit from the foreign banks that operate in Argentina but is having difficulty maintaining this uncollateralized arrangement as banks become more risk averse.)

A collateralized credit facility would be a voluntary arrangement between an emerging market government and a group of foreign banks and other financial institutions. Participation by the IMF or the World Bank on the same terms as the private lenders would create much greater confidence in these credits since countries are very reluctant to default on payments to the IMF and the World Bank. The participants would decide the maximum amount of foreign exchange credit that would be available on request and would agree in advance on the interest rate (or spread) that would be paid if the loan facility were actually exercised. The government would have the option to borrow these funds at any time during a period with a terminal date that is automatically maintained at two years into the future, subject to any of the parties being able to withdraw on two years' notice. The government would pay a fee to each of the potential lenders for this option to obtain credit under less favorable future circumstances. Each of the potential lenders might participate on equal terms or a more elaborate structure might be devised with some creditors taking more risk (e.g., being the last to be repaid) in exchange for higher fees and interest.

If it becomes necessary to use the loan facility, the borrowing government would require that all of the earnings of its exporters (or of exporters above some minimum size) be repatriated immediately and paid to a trustee institution like the Bank of England or the New York Federal Reserve. The trustee would transfer a fraction of these receipts to the creditors to service the newly incurred debt, with the specific fraction depending on the amount of debt incurred. The remainder of the export receipts would be transferred to the emerging market government which would pay the 
exporters the value of their exports in a combination of the local currency and the currency of the export earnings.

To make this operational on short notice, the country must have enacted legislation well in advance to establish the diversion of export earnings if it uses the credit facility. Currency controls would also be needed during the period of the loan, permitting only importers and others with specific needs to convert domestic funds into foreign exchange. The enforcement of the diversion would be easier if the G-7 countries required importers in their own countries to divert payments for imports to the trustee.

A collateralized credit facility can be much less expensive than accumulating and holding foreign exchange reserves as long as it is not actually utilized. If it is used, the exchange controls and the payment diversions would involve large administrative costs. Actions to evade these controls would waste resources. A country's decision to create a collateralized facility must reflect its judgement about whether the size of the potential credit could be large enough to deter irrational speculation and crises of contagion and to give the country sufficient adjustment time to deal with crises that do occur.

\section{Alternatives to Liquidity}

I have emphasized self-protection through increased liquidity because I believe that the other ideas that have been proposed are not suitable. I have already commented on the inadequacy of the past IMF programs and of the proposed new "enhanced lending facility". Three other ideas that are frequently discussed deserve brief comment.

\section{Economic Isolation.}


Prime Minister Mahathir has chosen to impose complete controls for the indefinite future on all capital inflows and outflows of Malaysia. This not only denies Malaysia the ability to supplement domestic savings with foreign capital but is likely to discourage firms from making direct investments in fear that controls will later prevent repatriation of profits. Efforts to evade controls will lead to waste and corruption.

The argument that such isolation is desirable because it allows Malaysia to stimulate its economy by lower interest rates is unconvincing since the same stimulus could be achieved with targeted tax incentives that offset the effect of high interest rates.

\section{$\underline{\text { A Currency Board }}$}

Argentina and Hong Kong operate modified versions of the textbook currency board system. In a pure currency board system, Argentina would hold one US dollar (or an equivalent amount of some other 'hard' currency) for every peso that is distributed as cash or as reserves in the commercial banks. Everyone would have the right to exchange pesos for dollars at that exchange rate. A currency board system, if strictly enforced, would prevent a successful run on the Argentinean peso because withdrawing foreign exchange reserves would force the central bank to reduce the money supply, thereby raising interest rates. The government is never forced to devalue because interest rates keep rising as the country loses reserves until interest rates are high enough to induce investors to stop selling pesos. In principle, this self-regulating mechanism discourages speculators so the interest rates need never rise to high levels.

The success of the currency board as a deterrent to speculators depends on a general confidence that the government would actually permit interest rates to keep rising as long as foreign exchange reserves are being depleted no matter how much damage those high rates do to the 
economy. If a collapse of domestic demand and sharp rise in unemployment would instead induce the government to bend the rules of the currency board, permitting the central bank to issue bank reserves without full foreign currency backing, the automatic confidence factor is gone and the currency board becomes only a promise of the government not to devalue or to pursue an inflationary momentary policy. .

Whatever its virtue as a signal of the government's intention to avoid inflation, the currency board is not a way of preventing currency crises. Indeed, if the Hong Kong government eventually succumbs to the current deepening recession in Hong Kong by devaluing the currency and reducing interest rates, Argentina's currency board would probably lose credibility and the basic notion of the currency board would be sent back to the textbooks of monetary history.

\section{Dollar Zone or Yen Zone}

One way to avoid currency crises is to abandon the local currency completely and to replace it with the dollar or yen. This in effect has happened in Europe where the euro has replaced the national currencies. Could Mexico adopt the dollar as its national currency or Thailand adopt the yen? The short answer is "no."

The countries that use the euro will have access to their national central banks as lenders of last resort. If commercial banks in Italy or Portugal are in trouble, their central banks will provide as many euros as the depositors want and a widespread bank run will be averted. Although Mexican commercial banks are estimated to have bad loans equal to 20 percent of more of GDP, the Mexican banking system does not collapse because the public knows that the Bank of Mexico can create pesos to replace the deposits of any bank that fails. But if those peso deposits were relabeled as dollar deposits, there would be no Mexican central bank with the ability to provide the dollars that 
depositors demand. The result would be widespread bank runs leading to a currency crisis as Mexicans sought to take their funds out of the country to the safety of US and other foreign banks.

The only way for Mexico to adopt the dollar as its currency would be to have American banks provide the Mexican banking services and to cede monetary policy to the Federal Reserve. Even if the Mexicans were willing to do so, creating a currency union for two such very different economies would cause serious economic problems for Mexico.

\section{Conclusion}

Large current account deficits, excessive short term foreign currency liabilities, and weak banking systems increase the likelihood of devastating currency crises, painful fluctuations in exchange rates, and externally driven swings in domestic interest rates. Political and business leaders in emerging market countries rightly ask themselves what can be done to reduce these risks. There is no substitute for sound economic policies: moderate trade deficits, low net levels of short-term foreign debts, and relatively sound banking systems. But even those countries that pursue such policies are at risk to the powerful forces of market contagion, shifts in risk aversion, and irrational speculation.

Because the IMF and other international organizations do not have the resources to act as lenders of last resort, the emerging market countries that want to prevent sharp currency declines must provide for their own protection through increased liquidity. Reductions in the extent of short term capital inflows would reduce the risk of balance sheet illiquidity. Much larger amounts of foreign exchange reserves than countries have traditionally held could be an important source of 
protection, flexibility, and confidence. Collateralized credit facilities with private institutions might provide the rapid access to additional liquidity in place of the missing (and infeasible) official lender of last resort. Each of these options is expensive but could prove far less costly than the damage of currency crises.

Cambridge MA

December 1998 